\title{
ANALISIS EMISI GAS BUANG HASIL PEMBAKARAN SOLAR DAN BIOSOLAR (B25) PADA FIRE TUBE BOILER
}

\author{
Winny Andalia ${ }^{1)}$, Sukarmansyah ${ }^{2)}$ dan Amin Fauzie ${ }^{2)}$ \\ ${ }^{1)}$ Program Studi Teknik Industri Universitas Tridinanti Palembang \\ ${ }^{2)}$ Program Studi Teknik Mesin Universitas Tridinanti Palembang \\ e-mail: winnyandalia90@gmail.com
}

\begin{abstract}
The use of biodiesel in boilers has great benefits because it reduces exhaust emissions. The purpose of this study is to test the quality of solar and biosolar raw materials as fuel from the boiler, analyze the concentration of pollutant gases (NOx, CO2, SO2) from the combustion of biosolar and diesel oil experimentally. The combustion system in the boiler tends to be simpler than compression ignition as is done with diesel engines. This research was conducted experimentally in a fire tube boiler, with a heat input rate of 60,000 kCal / hour and a pressure of 3 bar using biodiesel made from CPO (crude palm oil) as fuel. The mixture varies at 0, 5, 10, 15, 20 and 25\% biodiesel in a mixture with biosolar diesel (B0, B5, B10, B15, B20 and B25). This research was carried out experimentally by testing the exhaust gas emissions generated from the stack gas stack which is expected to produce low exhaust emissions and are environmentally friendly. The results show that the use of biodiesel reduces gas emissions by increasing the value of biodiesel in the mixture. The results showed that the lowest gas emissions were around 4.142\% (NOx); 12.50\% (SO2) and 7.9\% (CO2) contained in a mixture of 25\% biodiesel in fuel (B25).
\end{abstract}

Keywords: Biodiesel, CPO, Emission, Fire Tube Boiler

\section{PENDAHULUAN}

Pencemaran udara dewasa ini semakin menampakkan kondisi yang sangat memprihatinkan. Sumber pencemaran udara dapat berasal dari berbagai kegiatan antara lain industri, transportasi, perkantoran, dan perumahan. Berbagai kegiatan tersebut berkontribusi besar terhadap pencemaran udara dan menimbulkan efek buruk bagi kondisi atmosfer lingkungan. Oleh karena itu, untuk memenuhi kebutuhan udara bersih, pemerintah Indonesia membuat peraturan pemerintah RI No 41 Tahun 1999 tentang Pengendalian Pencemaran Udara.

Udara sebagai komponen lingkungan yang penting dalam kehidupan harus dipelihara dan ditingkatkan kualitasnya sehingga dapat memberikan daya dukung bagi mahluk hidup untuk dapat hidup secara optimal. Permasalahan lingkungan yang timbul akibat meningkatnya permintaan supplai energi yang tinggi menjadi suatu masalah besar bagi negara Indonesia. Salah satu aspek polusi lingkungan yaitu emisi gas buang seperti $\mathrm{SO}_{2}, \mathrm{CO}$, dan NOx dari pengoperasian boiler berbahan bakar minyak solar berbasis fosil dari suatu industri. Dampaknya terjadi penurunan kualitas udara ambien yang disebabkan oleh emisi gas pollutan dari cerobong (stack). Data World Recource Institue menyatakan bahwa kondisi atmosfer Indonesia berada pada level ke-14 di dunia yang dinyatakan dengan nilai absolute emission, setelah Meksiko. Hal ini menunjukkan emisi polutan yang terjadi di Indonesia cukup tinggi dan mempengaruhi dampak terhadap perubahan iklim di atmosfer.

Salah satu upaya dalam menyikapi perubahan iklim global yang terjadi di beberapa industri terkait yaitu dengan penggunaan bahan bakar nabati sebagai pengganti bahan bakar fosil seperti biosolar. Pada penelitian ini digunakan boiler berbahan bakar biosolar dan solar. Emisi gas buang $\left(\mathrm{SO}_{2}, \mathrm{CO}_{2}, \mathrm{NOx}\right)$ dianalisis menggunakan gas analyzer. Parameter yang diteliti adalah pengaruh penambahan bahan bakar solar dan biosolar pada fire tube boiler terhadap emisi gas buang yang dihasilkan.

\section{PERUMUSANAN MASALAH}

Berdasarkan Hasil pengujian pada kebanyakan mesin diesel dan boiler menunjukkan bahwa pada satu sisi penggunaan biosolar mampu memberikan efek penurunan emisi terutama pada parameter $\mathrm{SO}_{2}, \mathrm{PM}, \mathrm{CO}_{2}$ dan $\mathrm{HC}$, namun sebaliknya menunjukkan kecenderungan peningkatan terhadap emisi NOx [1]. Bagaimana menghasilkan kondisi optimum emisi gas buang yang ramah 
lingkungan dalam penggunaan bahan bakar biosolar dan solar pada alat fire tube boiler secara eksperimen.

\section{TINJAUAN PUSTAKA \\ Boiler}

Salah satu peralatan yang sangat penting di dalam suatu pembangkit tenaga listrik adalah Boiler (Steam Generator) atau yang biasanya disebut ketel uap. Alat ini merupakan alat penukar kalor, dimana energi panas yang dihasilkan dari pembakaran diubah menjadi energi potensial yang berupa uap. Uap yang mempunyai tekanan dan temperatur tinggi inilah yang nantinya digunakan sebagai media penggerak utama Turbin Uap. Energi panas diperoleh dengan jalan pembakaran bahan bakar di ruang bakar. Geometri boiler dapat berbentuk silinder vertikel maupun horizontal. Proses pembentukan uap yang terjadi pada ketel uap adalah sebagai berikut: mula-mula tangki diisi dengan air, kemudian tangki dipanasi hingga temperatur dalam tangki akan naik mencapai titik didih maka terbentuk uap. Uap yang terbentuk pada temperatur didih ini disebut uap jenuh.

\section{Fire Tube Boiler}

Pada fire tube boiler, gas panas melewati pipa-pipa dan air umpan boiler ada didalam shell untuk diubah menjadi steam. Fire tube boiler biasanya digunakan untuk kapasitas steam yang relatif kecil dengan tekanan steam rendah sampai sedang. Sebagai pedoman, fire tube boiler kompetitif untuk kecepatan steam sampai $12.000 \mathrm{~kg} / \mathrm{jam}$ dengan tekanan sampai $18 \mathrm{~kg} / \mathrm{cm}$. Fire tube boiler dapat menggunakan bahan bakar minyak bakar, gas atau bahan bakar padat dalam operasinya. Untuk alasan ekonomis, sebagian besar fire tube boiler dikonstruksisebagai “paket” boiler (dirakit oleh pabrik) untuk semua bahan bakar [2].

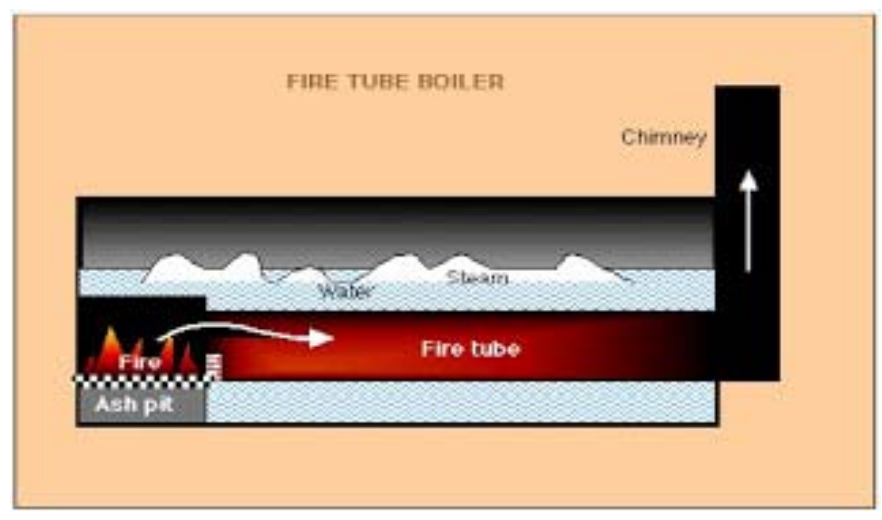

Gambar 1. Fire Tube Boiler

\section{Biodiesel}

Biodiesel merupakan bahan bakar yang terdiri dari campuran mono-alkyl ester dari rantai panjang asam lemak, yang dipakai sebagai alternatif bagi bahan bakar dari mesin diesel dan terbuat dari sumber terbaharui seperti minyak sayur atau lemak hewan.

Sebuah proses dari transesterifikasi lipid digunakan untuk mengubah minyak dasar menjadi ester yang diinginkan dan membuang asam lemak bebas. Setelah melewati proses ini, tidak seperti minyak sayur langsung, biodiesel memiliki sifat pembakaran yang mirip dengan diesel (solar) dari minyak bumi, dan dapat menggantikannya dalam banyak kasus. Namun, lebih sering digunakan sebagai penambah untuk diesel petroleum, meningkatkan bahan bakar diesel petrol murni ultra rendah belerang yang rendah pelumas [3].

Biodiesel merupakan senyawa kimia sederhana dengan kandungan enam sampai tujuh macam ester asam lemak. Biodiesel didefinisikan sebagai metil ester dengan panjang rantai karbon antara 12 sampai 20 dari asam lemak turunan dari lipid contohnya minyak nabati atau lemak 
hewani. Komposisi dan sifat kimia dari biodiesel tergantung pada kemurnian, panjang pendek, derajat kejenuhan, dan struktur rantai alkil asam lemak penyusunnya [4].

Idealnya, transesterifikasi berpotensi menjadi cara yang lebih efisien untuk mengubah struktur molekul minyak dari yang besar menjadi lebih kecil, dari yang bercabang menjadi molekul rantai lurus berdasarkan jenis yang diperlukan dalam mesin pembakaran minyak solar biasa [4].

Tabel 1. Karakteristik biodiesels (SNI -04-7182-2006)

\begin{tabular}{|c|c|c|c|c|}
\hline No & Parameter dan satuannya & Batas Nilai & Metode Uji & Metode setara \\
\hline 1 & Densitas pada $40^{\circ} \mathrm{C}, \mathrm{Kg} / \mathrm{m} 3$ & $850--890$ & ASTM D 1298 & ISO 3675 \\
\hline 2 & Viskositas kinematik pada $40^{\circ} \mathrm{mm} 2 / \mathrm{s}$ (cSt) & 2,3-6,0 & ASTM D 445 & ISO 3104 \\
\hline 3 & Angka Setana & Min. 51 & ASTM D 613 & ISO 5165 \\
\hline 4 & Titik nyala (flash point) pada $0^{\circ}$ & Min.100 & ASTM D 93 & ISO 2710 \\
\hline 5 & Titik kabut (Cloud Point) & Max.18 & \multicolumn{2}{|c|}{ ASTM D 2500} \\
\hline 6 & Titik Tuang (Pour Point) & Max.18 & \multicolumn{2}{|c|}{ ASTM D97 } \\
\hline 7 & Korosi bilah tembaga (3 jam,500C) & Max.3 & ASTM D 130 & ISO 2160 \\
\hline 8 & $\begin{array}{l}\text { Residu karbon,\%-berat, } \\
\text { Dalam contoh asli Dalam } 10 \% \text { ampas Distilasi }\end{array}$ & $\begin{array}{l}\text { Max.0,05 } \\
\text { Max.0,03 }\end{array}$ & ASTM D 4530 & ISO 10370 \\
\hline 9 & Air dan sediman,\%-volume & Maks.0,05 & ASTM D 2709 & - \\
\hline 10 & Temperatur distilasi 90\%, 0C & Maks.360 & ASTM D 1160 & - \\
\hline 11 & Abu tersulfatkan,\%-berat & Maks 0,02 & ASTM D 874 & ISO 3987 \\
\hline 12 & Belerang,ppm-b (mg/kg & Maks.100 & ASTM D 5453 & Pren ISO 20884 \\
\hline 13 & Fosfor,ppm-b (mg/kg) & Maks.10 & AOCS Ca 12-55 & FBI-A05-03 \\
\hline 14 & Angka asam,mg-KOH/gr & Maks.0,8 & AOCS Cd 3-63 & FBI-A01-03 \\
\hline 15 & Gliserol bebas,\%-berat & Maks.0,02 & AOCSCa 14-56 & FBI-A02-03 \\
\hline 16 & Gliserol total,\%-berat & Maks.0,24 & AOCS Ca14-56 & FBI-A02-03 \\
\hline 17 & Kadar ester alkil,\%-berat & Min.96,5 & Dihitung *) & FBI-AO3-03 \\
\hline 18 & Bilangan iodine,g-I2/100g & Maks.115 & AOCS Cd1-25 & FBI-AO4-03 \\
\hline 19 & Uji Halphen & negatif & AOCS Cb 1-25 & FBI-AO6-03 \\
\hline
\end{tabular}

Biodiesel merupakan bahan bakar yang berwarna kekuningan yang viskositasnya tidak jauh berbeda dengan minyak solar. Oleh karena itu campuran bio-diesel dengan minyak solar dapat dimanfaatkan sebagai bahan bakar kendaraan berbahan bakar minyak solar tanpa merusak atau memodifikasi mesin [5,6]. Data Tabel 1 di atas menampilkan Standar Nasional Indonesia (SNI) untuk Biodiesel yang diproduksi di Indonesia. Salah satu keuntungan penambahan biodiesel sebagai campuran dengan minyak solar adalah peningkatan lubrisitas bahan bakar dan mereduksi emisi gas buang. Proses paling umum dalam pembuatan biodiesel dikenal sebagai proses transesterifikasi dengan bahan baku minyak nabati, lemak hewani dan minyak goreng bekas dan direaksikan dengan alkohol dengan adanya suatu katalis tertentu.

Minyak solar merupakan jenis bahan bakar minyak untuk mesin diesel yang bersifat tidak terbarukan. Diperlukan upaya untuk mengurangi ketergantungan terhadap minyak solar. Salah satu energi alternatif sebagai upaya pengurangan ketergantungan tersebut adalah biodiesel. Namun biodiesel dalam keadaan murni (B100) memiliki beberapa kekurangan jika digunakan dalam keadaan murni. Tindakan umum yang dilakukan untuk mengatasi kekurangan B100 sebagai bahan bakar adalah dilakukan blending dengan minyak solar pada formulasi blending tertentu [7]. Blending adalah suatu proses pencampuran untuk mendapatkan produk atau umpan yang memenuhi persyaratan atau spesifikasi yang diperlukan. Untuk blending di Indonesia baru ada B5 atau yang biasa kita kenal dengan biosolar. Sampai saat ini formulasi terbaik yang dapat diterapkan dengan kondisi mesin yang sudah ada dibanyak mesin transportasi yang digunakan adalah melakukan blending dengan formulasi blending mencapai 20\%. Istilah B20 ini menunjukkan atas 20\% biodiesel dan $80 \%$ solar. Begitu juga dengan B5 yang berarti 5\% biodiesel dan 95\% solar. Istilah lain seperti B10, B20 dan B30 adalah mengikuti sesuai konsentrasi biodisel yang ditambahkan [8]. Angka setana pada bahan bakar minyak diesel menunjukkan kualitas penyalaan apabila nilai angka setana rendah akan memerlukan suhu yang sangat tinggi untuk penyalaannya, sebaliknya apabila 
angka setana tinggi memerlukan titik penyalaan sendiri yang lebih rendah sehingga angka setana yang lebih tinggi akan mengurangi angka detonasi di dalam mesin [9].

Uji B0, B10, B20, B30, B50 dan B100 (biodiesel murni) terhadap performa mesin dievaluasi melalui torsi, daya, dan bahan bakar spesifik konsumsi, sementara emisi dievaluasi melalui karbon monoksida (CO), hidrokarbon (HC), partikulat (PM), karbon dioksida (CO2), dan polutan NOx. Hasil menunjukkan bahwa konten yang lebih tinggi dari biodiesel sawit dapat mengurangi emisi $\mathrm{CO}, \mathrm{HC}, \mathrm{PM}$, dan $\mathrm{CO} 2$. Ditemukan bahwa penambahan biodiesel bisa meningkatkan tenaga dan torsi [10]. Campuran biodiesel pada solar dapat membantu mengendalikan polusi udara dan mengurangi tekanan pada sumber daya yang langka tanpa mengorbankan kekuatan mesin dan ekonomi secara signifikan. Namun, banyak penelitian lebih lanjut tentang optimasi dan modifikasi pada mesin, kinerja suhu rendah pada mesin, instrumentasi baru dan metodologi untuk pengukuran harus dilakukan ketika petroleum diesel diganti sepenuhnya oleh biodiesel [11,12].

\section{METODE PENELITIAN}

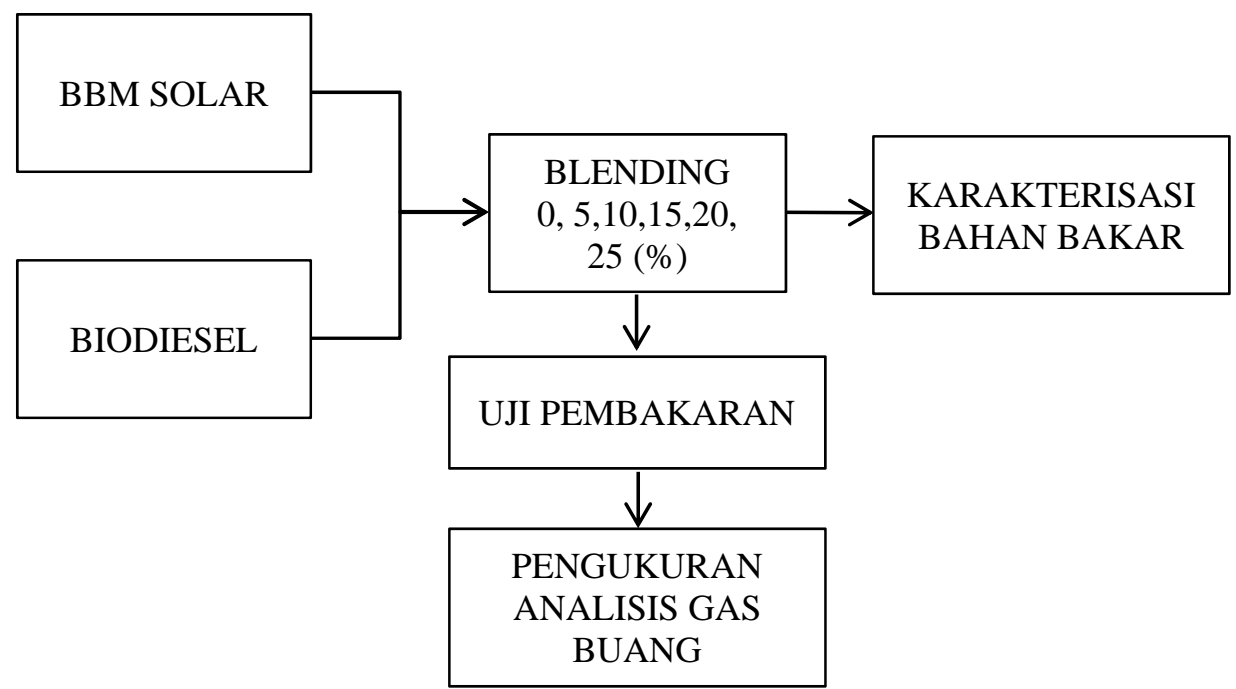

Gambar 2. Blok diagram kerja pengambilan data secara eksperimen

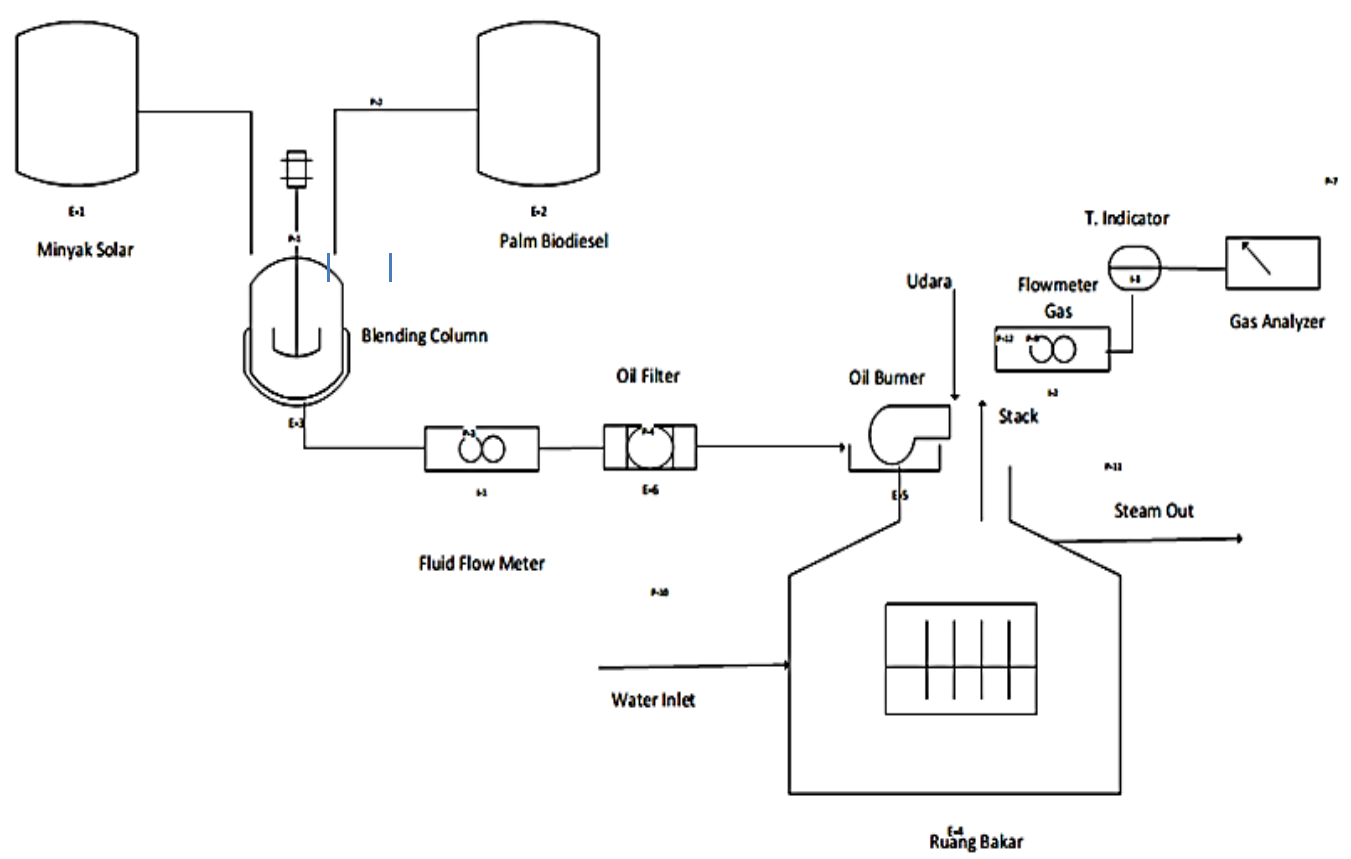

Gambar 3. Sistem rangkaian alat penelitian 
Tabel 2. Hasil analisis bahan bakar

\begin{tabular}{|c|c|c|c|c|c|c|c|}
\hline \multicolumn{2}{|c|}{ Bahan Bakar } & \multirow{2}{*}{ Bxx } & \multirow{2}{*}{$\begin{array}{l}\text { Viskositas } \\
\text { (cst) }\end{array}$} & \multirow{2}{*}{$\begin{array}{l}\text { Water Content } \\
\text { (ppm) }\end{array}$} & \multirow{2}{*}{$\begin{array}{l}\text { Heating Value } \\
\quad(\mathrm{kkal} / \mathrm{kg})\end{array}$} & \multirow{2}{*}{$\begin{array}{c}\text { Cetane } \\
\text { Number }\end{array}$} & \multirow{2}{*}{$\begin{array}{c}\text { Flash } \\
\text { Point }\left(^{\circ} \mathrm{C}\right)\end{array}$} \\
\hline Solar & Biodiesel & & & & & & \\
\hline $100 \%$ & $0 \%$ & B0 & 2,962 & 26,6 & 10737 & 47,4 & 83,1 \\
\hline $95 \%$ & $5 \%$ & B5 & 2,997 & 10,4 & 10629 & 50,6 & 82,3 \\
\hline $90 \%$ & $10 \%$ & B10 & 3,072 & 7,4 & 10509 & 54,9 & 82,3 \\
\hline $85 \%$ & $15 \%$ & B15 & 3,118 & 4,5 & 10488,5 & 56,2 & 82,3 \\
\hline $80 \%$ & $20 \%$ & B20 & 3,164 & 2,6 & 10468 & 57,5 & 82,3 \\
\hline $75 \%$ & $25 \%$ & B25 & 3,118 & 1,5 & 10252 & 56,2 & 82 \\
\hline
\end{tabular}

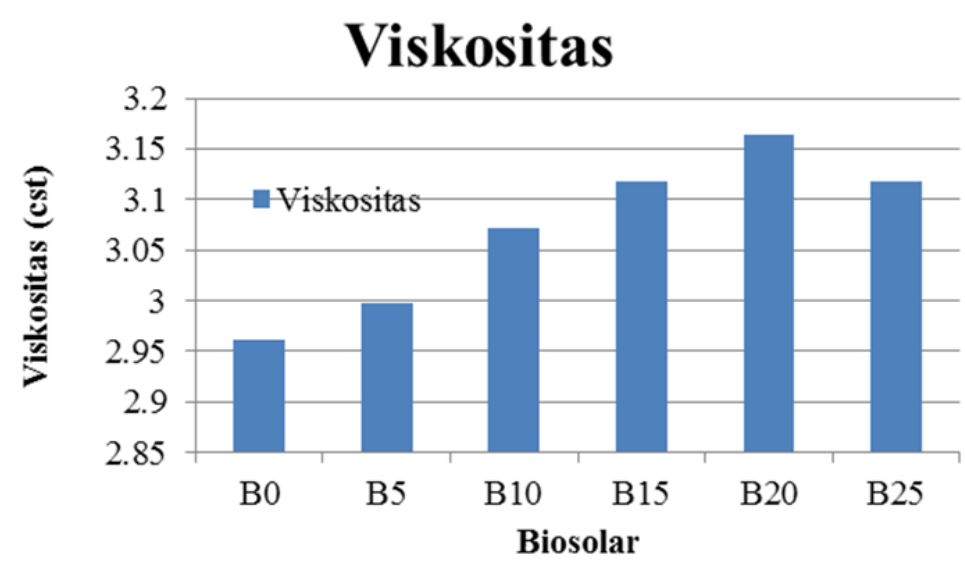

Gambar 4. Pengaruh biosolar terhadap viskositas

Dari grafik batang diatas dapat dilihat bahwa pada campuran bahan bakar B0, B5, B10, B15, B20 an B25 mengalami peningkatan terhadap viskositasnya karena pengaruh dari pencampuran biodiesel terhadap minyak solar. Hal ini menunjukkan bahwa semakin tinggi viskositas bahan bakar yang lebih tinggi dapat menyulitkan proses atomisasi bahan bakar, sehingga berakibat pada penurunan daya mesin. Daya mesin yang lebih rendah dapat menyebabkan penurunan efisiensi termal mesin.

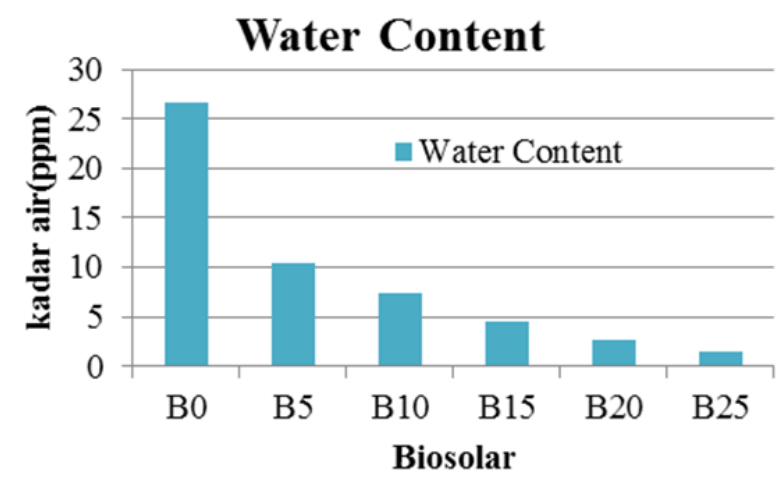

Gambar 5. Pengaruh biosolar terhadap kadar air (Water Content)

Pada grafik batang di atas menunjukkan kecenderungan bahwa semakin besar campuran biodiesel pada bahan bakar solar maka semakin kecil kandungan airnya karena sifat fisika kimia dari biodiesel. Pada B0 (solar murni) menunjukkan kadar air yang tinggi sebesar 26,6 ppm atau setara dengan 0,00266\% dibandingkan (B5, B10, B15, B20 dan B25) sedangkan pada B25 kadar air makin rendah sebesar 1,5 ppm setara dengan 0,00015\%. Berdasarkan Standar Nasional Indonesia (SNI) 2006 kadar air yang terkandung dalam biodiesel maksimum 0.05\%. Kadar air merupakan salah satu tolak ukur mutu biodiesel, dan dari hasil analisis di atas menunjukkan bahwa kadar air 
memenuhi syarat mutu dari biodiesel. Menurut Syamsidar [13], semakin kecil kadar air dalam minyak maka mutunya akan semakin baik karena akan memperkecil terjadinya hidrolisis yang dapat menyebabkan kenaikan kadar asam lemak bebas. Kandungan air dalam bahan bakar dapat juga menyebabkan turunnya panas pembakaran, berbusa dan bersifat korosif jika bereaksi dengan sulfur karena akanmembentuk asam. Pada temperatur yang sangat dingin, air yang terkandung dalam bahan bakar membentuk kristal dan menyumbat aliran bahan bakar dan bersifat korosif.

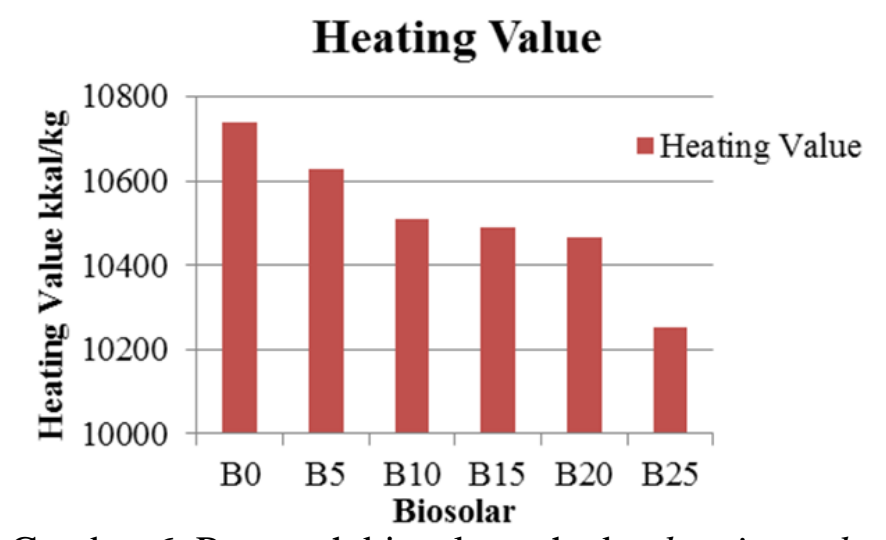

Gambar 6. Pengaruh biosolar terhadap heating value

Dari data eksperimen yang telah dilakukan pada pengujian bahan bakar biosolar, terlihat bahwa grafik diatas mengalami penurunan secara signifikan pada variasi campuran biosolar B0, B5, B10, B15, B20 dan B25 terhadap nilai kalornya (heating value). Penurunan ini disebabkan karena biodiesel memiliki nilai kalor 5-13\% lebih rendah dibandingkan minyak solar, sehingga bila diaplikasikan pada sistem bahan bakar lebih banyak massa bahan bakar yang diinjeksikan untuk mencapai stoikiometri pembakaran sehingga berpengaruh pada peningkatan konsumsi bahan bakar. Selanjutnya jika temperatur bahan bakar dinaikkan, maka konsumsi bahan bakar yang dibutuhkan oleh mesin menjadi lebih besar. Hal ini sama dengan pernyataan Murni bahwa peningkatan bahan bakar ini dapat terjadi karena peningkatan temperatur bahan bakarnya yang menyebabkan bahan bakar menjadi lebih mudah terbakar, sehingga akan mempersingkat periode pra-pembakaran (ignition delay) [14].

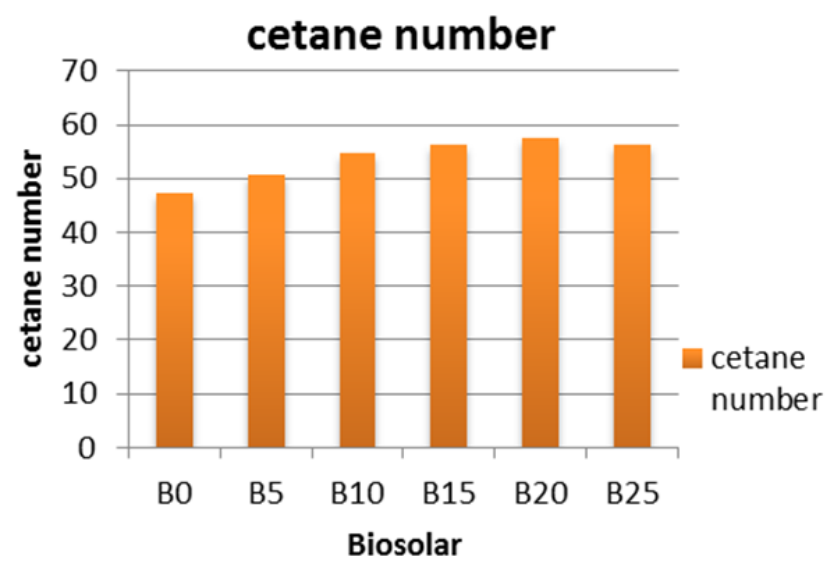

Gambar 7. Pengaruh biosolar terhadap cetane number

Peningkatan nilai cetane number pada campuran biosolar B0, B5, B10, B15, B20 dan B25 terjadi karena pengaruh pada waktu tunda penyalaan, hal ini dapat mempercepat waktu pembakaran. Nilai cetane number paling tinggi berada di campuran biosolar B25 sebesar 57,5. Cetane number merupakan ukuran yang menunjukkan kemampuan bahan bakar diesel untuk dikompresi dalam mesin. Prihandana menyatakan bahwa bilangan setana yang tinggi menunjukkan 
bahwa biodiesel dapat menyala pada temperatur yang relatif rendah begitu juga sebaliknya sehingga akan mudah terbakar di dalam silinder pembakaran mesin dan tidak terakumulasi [15].

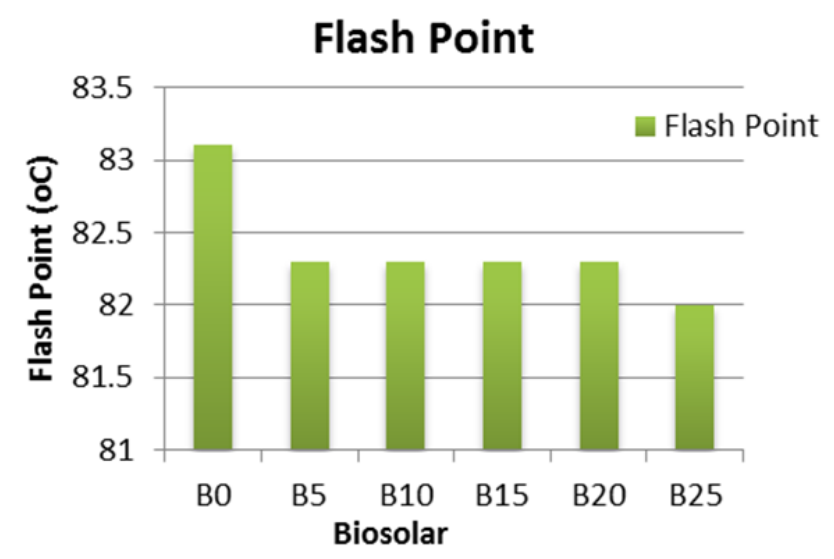

Gambar 8. Pengaruh biosolar terhadap flash point

Flash point atau titik nyala adalah temperatur terendah dari contoh pada saat mana api pencoba dapat menyalakan uap diatas permukaan contoh pada saat pemeriksaaan. Analisis flash point ini menggunakan metode tes ASTM D-93 dengan nilai minimal untuk flash point sebesar $60^{\circ} \mathrm{C}$. Untuk analisis flash point ini menggunakan peralatan utama yaitu Alat Flash Point Pensky Martens Closed Cup dan termometer ASTM $1^{\circ} \mathrm{C}$. Terlihat pada grafik diatas bahwa flashpoint ratarata berkisar pada temperature $80-83^{\circ} \mathrm{C}$ sehingga sudah memenuhi standar SNI yang berlaku. Titik nyala sendiri tidak berkaitan langsung dengan kerja mesin, namun sangat penting untuk keamanan dan keselamatan penyimpanan biodiesel. Menurut Suryani [16], titik nyala yang tinggi akan memudahkan penanganan bahan bakar karena tidak perlu disimpan pada suhu rendah, sebaliknya titik nyala yang terlalu rendah akan membahayakan karena tingginya resiko terjadi penyalaan.

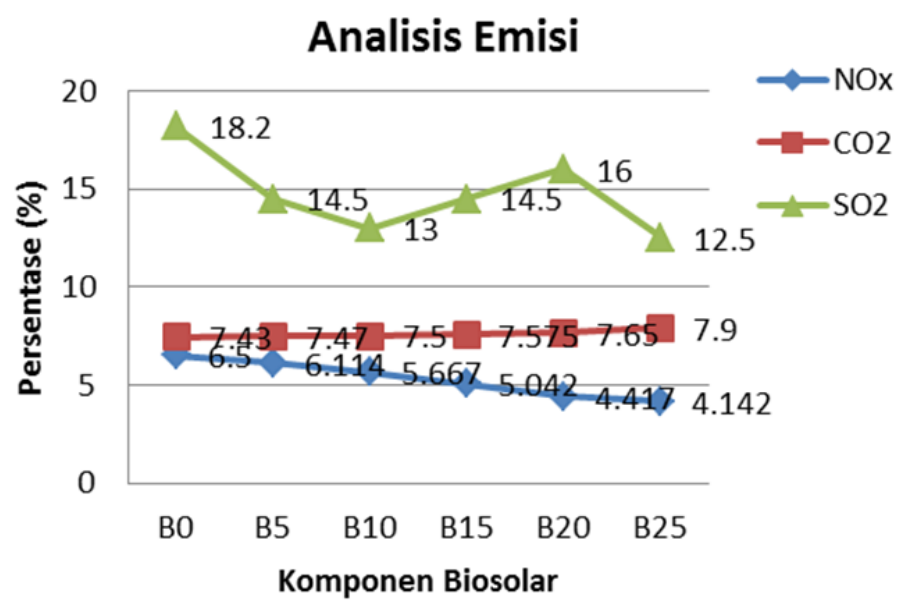

Gambar 9. Hasil analisis emisi gas buang

\section{SIMPULAN}

Berdasarkan data dari hasil eksperimen dapat disimpulkan bahwa pemanfaatan biodiesel memiliki keunggulan bagi industri boiler tipe fire tube atau pipa bola api karena dapat mengurangi emisi gas buang dibandingkan minyak diesel/solar. Emisi gas polutan menurun seiring dengan meningkatnya kandungan biodiesel dalam campuran. Hasil penelitian menunjukkan bahwa emisi gas terendah yaitu sekitar 4,142\% (NOx); 12,50\% $\left(\mathrm{SO}_{2}\right)$ dan 7,9\% $\left(\mathrm{CO}_{2}\right)$ yang terdapat pada campuran 25\% biodiesel dalam bahan bakar (B25). 


\section{DAFTAR PUSTAKA}

[1]. Bowman, C. T., (2011). Control of Combustion-Generated Nitrogen Oxide Emissions: Technology Driven by Regulation, Proc. Combustion Institute 24, pp. 859-878, 1992

[2]. Raharjo W. D dan Karnowo.2008. Mesin Konversi Energi. Semarang: Universitas Semarang Press.

[3]. Badan Standardisasi Nasional, B. (2006). SNI 04-7182-2006. Jakarta: Badan Standarisasi Nasional.

[4]. Djamin, M., S.,Wirawan, S.S. (2010). Pengaruh Komposisi Biodiesel Terhadap Kinerja Mesin Dan Emisi Gas Buang. Jurnal Teknik Lingkungan 11 (3): 381-387.

[5]. Komariah, L.N., Arita, S., Wirawan, S.S., Yazid, M., Novia. (2013). Emission factors of biodiesel combustion in industrial boiler: A comparison to fossil fuel. Journal of Renewable and Sustainable Energy, 5, 052005.

[6]. Habib, M. A., Elshafei, M., \& Dajani, M. (2008). Influence of combustion parameters on NOx production in an industrial boiler. Computers and Fluids 37 , 12-23.

[7]. Komariah, L.N., Arita, S., Wirawan, S.S., Yazid, M., Novia.(2013). Effects of Palm Biodiesel Blends on Fuel Consumption in Fire Tube Boiler. Applied Mechanics and Materials Vol. 391 (2013) pp 93-97

[8]. Um, S., and S. W. Park. "Numerical Study on Combustion and Emission Characteristics of Homogeneous Charge Compression Ignition Engines Fueled with Biodiesel ." Energy Fuel, 2009: 24, 916-927.

[9]. Setyadi, P., . S.C. Wibowo. Jurnal Konversi Energi dan Manufaktur UNJ, Edisiterbit II Oktober 2015: 93-99.

[10]. Wirawan, S. S., A. H. Tambunan, and M. Djamin. "The Effect of palm biodiesel fuel on performance and emission of the automotive diesel engine,”." Eng. Int. CIGR E-J., 2008: X, $1-13$.

[11]. Xue, J., Grift, T. E., \& Hansen, A. C. (2011). Effect of biodiesel on engine performances and emissions. Renewable and Sustaianble Energy Reviews 15, 1098-1116.

[12]. Yuan, W., Hansen, A. C., \& Zhang, Q. (2003). Predicting The Physical Properties of Biodiesel for Combustion Modeling. American Society of Agricultural Engineers 46 (6), 1487-1493.

[13]. Syamsidar, H. S. 2010. Pembuatan dan uji kualitas biodiesel dari minyak jelantah. Jurnal Teknosains, volume 7 (2): 1-22.

[14]. Murni. (2013). Pengaruh Temperatur Solar Terhadap Performa Mesin Diesel Direck Injection Putaran Konstan. Semarang: Universitas Diponegoro.

[15]. Prihandana, R., R. Hendroko dan M. Nuramin. 2006. Menghasilkan Biodiesel Murah Mengatasi Polusi dan Kelangkaan BBM. PT. Agromedia Pustaka. Jakarta.

[16]. Suryani, A. 2009. Penurunan asam lemak bebas dan transesterifikasi minyak jelantah menggunakan kopelarut metil tersier butil eter (MTBE). Skripsi Fakultas Teknik. Universitas Sebelas Maret. Surakarta. 